\title{
Strategic Staffing and Motivation in the Nigerian Civil Service (Kaduna State as a Case Study)
}

\author{
Olaniyan Timothy A. ${ }^{1}$, Olaniyan Enoch J. ${ }^{2}$ and Ayangbekun Oluwafemi J..$^{3 *}$ \\ ${ }^{1}$ Redeemer's College of Technology \& Management (RECTEM) \\ Km. 46, Lagos - Ibadan Expressway. \\ Ogun State, Nigeria. \\ ${ }^{2}$ Department of Accounting \\ Redeemer's College of Technology \& Management (RECTEM) \\ Km. 46, Lagos - Ibadan Expressway. \\ Ogun State, Nigeria. \\ ${ }^{3}$ Department of Computer Science \\ Redeemer's College of Technology \& Management (RECTEM) \\ Km. 46, Lagos - Ibadan Expressway. \\ Ogun State, Nigeria. \\ *Corresponding author's email: ayangbekunoj [AT] gmail.com
}

\begin{abstract}
The study "strategic staffing study of Kaduna state civil commission both by academic and service commission continue to be well-research topic both by academic and commercial firms. The aim of strategic staffing and motivation is to have well motivated employee as well as having managers with the possibility to motivate others. The focus is on the factors managers use to motivate employees and differences regarding gender and age. The purpose with the study is to provide a better understanding of the employee motivation issues in Kaduna state government, with emphasis on the five selected ministries in Kaduna state, Nigeria. i.e. Ministry of Environmental and Natural Resources, Education, Town Planning, water Resources and Youth and Sports. The findings show that motivation in its various forms has a direct impact on the performance Of employees. Today employees are more motivated by intrinsic factors rather than extrinsic which dominated in the past, but none of the two can be overlooked by managers when motivating their employees, It is recommended that both internal and external motivational factors should be explored by managers while managers themselves should be performance driven, an attribute which is a motivational factor in itself. Survey method was used in the research and simple percentages were also used in the interpretation of the data analysis.
\end{abstract}

Keywords - Employee, Ministry, Motivation, Strategic

\section{INTRODUCTION}

\subsection{Study Background}

Nigeria is known as one of the developing countries that is characterized by abject poverty, illiteracy, unemployment and ignorance. To alleviate the suffering of the people and cushion the effect of these economic and social problems, the Federal Government cannot do it alone. In effect, the government should encourage the establishment of private sector organizations. Motivation has become one of the important indispensable factors in management towards achievement of the organizational goals and objective. It is an acknowledged fact that one of the major problems facing us in Nigeria today especially in the public sectors is lack of devotion and loyalty to work. Adebayo (2010). Every organization today is concerned with what should be done to achieve and sustain high level of performance through people. This means giving close attention to how individuals can be best motivated through such means of strategic staffing and motivation; as incentives, rewards, leadership and importantly, the work they do and the organization content within which they carry out their duties.

One question management most frequently ask is 'How can employee be motivated'? In order to ensure success and avoid the employment of faulty motivational device, it is imperative for management to bear it in mind that staff comes to an organization with their work needs and drives (Bechet, 2006). Motivating staff becomes less tedious when management discovers the needs and expectations of employees and what reward they can see from their employment (Mullins, 2005). In trying to find out what motivates workers, the Nigeria Civil Service commission must create an 
environment that encourages workers to do what is in the organization's best interest that is by integrating the establishment's desired goals with their desired rewards.

The challenge to management therefore, is to recognise and understand the impact of various motivational techniques on individual and group behaviours within the organization and the success or failure of motivation rests on management's ability to match the nee4s of the workers with appropriate incentives (Robbins, 2008).

\subsection{Statement of the Research Problem}

To enhance performance, strategic staffing and motivation remains one of the most indispensable factors of the management imperatives in the pursuit of the organizational goals and objectives. It is a well-known fact that one of the major problems facing Nigeria today is the lack of commitment, devotion and loyalty to work in both ministries and private sectors at large. Organizational or individual achievement is not accomplished when the motivation is used to manipulate and control individuals.

All organizations have different key qualities which form the personality of the organization which staff want to belong to and in order to be successful the organization need to maintain the value which brought the people employed to the organization. A part of success is to recruit people who are motivated by inner drives and wait to be in the organization therefore the Civil service have to communicate, trust, respect and give gratitude to their staff.

\subsection{Research Questions / Hypothesis}

Research questions or hypotheses arc extensions of the research problem. Therefore to facilitate effective realization of the aforementioned research objectives the following research-questions were posed.

- To what extent are the civil servants satisfied with the current motivation strategy?

- How does strategic staffing affect the effectiveness of the Nigerian Civil Service?

- Is work performance-hinged on motivation factor?

- Why Staff need to be motivated in performing their job?

- Which of the staff welfare services is the most important to Nigerian Civil Service?

- What is the relationship between motivation and performance in the workplace?

- What motivational factors yield the best result in terms of performance?

- How can Nigerian Civil Service act on complain brought forward by staff?

- What benefits do staff stand to gain in providing quality service to the commission?

- What other strategies can the Nigerian Civil Service employ to ensure effective performance and recruiting system?

\section{BACKGROUND REVIEW}

\subsection{Historical Background}

When Nigeria gained her independence in 1960 from the British colonial authority, the public service commission was entrenched in the constitution of Nigeria to the function of appointments, promotion and discipline in the public service; particularly as government business were organized under departmental establishment such as: Public works department, Treasury department, Forestry department, Health department, the Nigerian Railways, the Electricity board, the Telecommunication board and the Nigerian Harbour to mention but a few.

However, strategic management identifies and pursues the organisation's mission by aligning the organisation's internal capabilities with the external demands of its environment. This is achievable by considering the basic five steps of strategic (Figure 1).

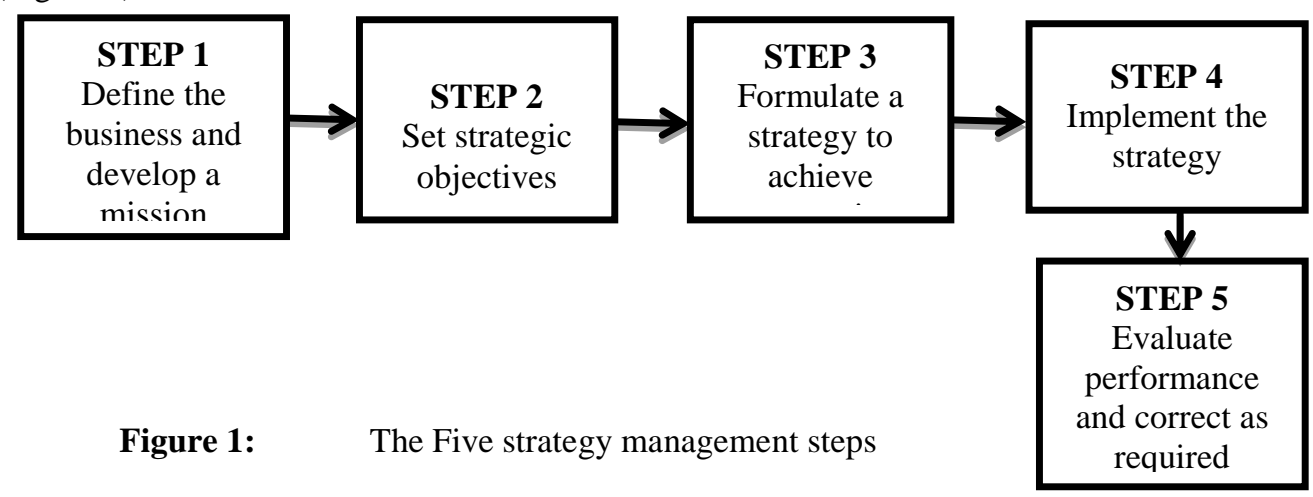




\subsection{Strategic Staffing Policies}

Strategic staffing involves putting together a combination of workers both internal and external strategically to meet the needs of the organization and realities of the labour market by determining how best to organize 'the people and resources to meet the organization's needs on any business environment (Drunker, 1998).

The question of what motivates workers to perform effectively is not an easy one to answer. The difficulty is that the researchers involved have to make assumptions about the motives for behaviour that they have observed and recorded. For an effective talent management strategy there is need to build an employer branding intervention. This study examines research literature on employer staffing and person- organization fit by investigating the process of developing effective employer brand intervention through a case study.

Conversely, a good workforce, according to Levering (2004) is believed to produce higher quality product, support more innovation, have the ability to attract more talented people, and experience less resistance to change and lower turnover costs, all of which translate directly into a better line. Therefore, Organizational effectiveness depends on loading the right people on the right bus, Collins (2001), to meet rapidly changing work environments (Bechet, 2006).

\subsection{Staff Sourcing}

Adeleke (2011) said that company can adopt different methods of recruitment for selecting people in the public service as well as the companies. These methods are: Internal sources and External sources (Table 8).

\subsubsection{Internal Sourcing}

Internal sources of recruitment refer to obtaining people for job from inside the establishment (Adeleke, 2011). Inotherword, internal sourcing is the practice of advertising a new or recently vacated position an establishment. It is most preferred because little or no training is needed and expenses that include advertising for a new employee and running background checks are spared which also fosters loyalty and parity among team workers. Employees see this method as competence being rewarded and morale and performance may thus be enhanced. On the other hand, current employee who apply for jobs and do not get them may become discontented.

\subsubsection{External Sourcing}

This is a method of recruitment that conducts an employee candidate search through external recruitment tools, such as job boards, newspaper advertisement and trade publication announcement. External sourcing is also used when the open position is not able to be filled by a current employee because of the technicality or specialty of the position.

This system of staff sourcing mostly involves the use of third party, Advertising (Adeyeye, 2011), Employment agencies, Referral (Soannes, 2004) and Internet Search.

\subsection{Orientation and Training in Kaduna State Government Ministries}

Employees' orientation involves providing new employees with basic information about the employer. In many organizations, employees receive an orientation hand book to facilitate this which contains information like history like history of the organization, function of each staff, Dos and Don'ts etc. Orientation also aims to familiarize the new employee with the organization and his or her co-workers, providing information about working conditions.

At Kaduna State Government, the aim of orientation and training is not just to familiarize workers with their new jobs, instead, it is to socialize new employees and thus foster a high level of commitment to and identification with the local government values, traditions and goals. Therefore, the 12 weeks orientation/training/socialization programme. This process involves teaching employees such core Kaduna State Government values as standing behind the council, taking the initiative and being able to work in teams.

\subsection{Employee Appraisal \& Compensation}

Once employee has been at work for sometime, their performance should be appraised or evaluated; appraisal provides an opportunity for management to give employees feedback on their job performance. Managers use several techniques to appraise their employee's performance; however, the most familiar is a performance appraisal form. This form list several job characteristics (like quality of work) and provides a rating scale from outstanding to unsatisfactory along with short definitions of each rating. The form also provides space for particularly good or particularly bad incidents of the employee's performance. Performance appraisal often leads to personnel action such as promotion, termination and discipline.

\subsection{Theory of Motivation}

Motivation is a process of guiding conduct and influencing people so that they can towards the achievement of group goals. These involve creating the right organizational conditions and the right of occupational that develop their 
potentials and strive for superior performance. But based on the expectancy theory, it has been deduced that that the strength of a tendency to act in a certain way depends on the strength of an expectation that the act will be followed by a given outcome, and on the attractiveness of the outcome to the individual.

This implies that the attractiveness of the reward, reward linkage/performance assurance and efforts/performance linkage are the 3 basic variables for motivation (Figure 2)

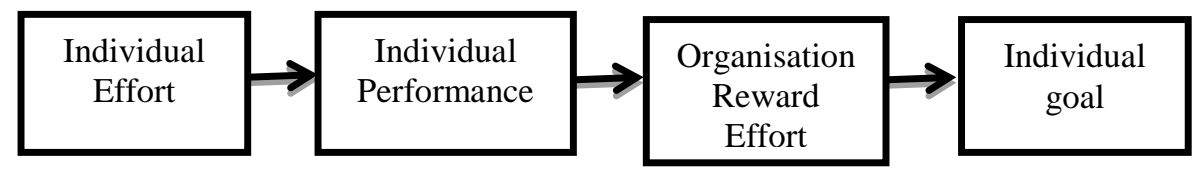

Figure 2: $\quad$ Expectancy Model

\section{RESEARCH DESIGN}

This is used here for the purpose of obtaining data to enable the researcher answer the research questions. It is an outline or scheme that serves as a useful guide to the researcher in his efforts to generate data for the study. It entails sampling procedure employed, sample size, research instrument, sources of data e.t.c. However, this research was designed to evaluate the practice of strategic staffing and motivation in the Nigeria Civil Service of Kaduna State using a case study with particular emphasis of Kaduna State staff at Ministry of Environmental and Natural Resources, Education, Town Planning and Survey, Water Resources, Youth/Sport and Social Development to evaluate motivation as a tool to enhance employee's performance, taking into consideration all the necessary factors that may contribute to the success of the research effort.

\subsection{Population of the Study}

The population of the study consists of five (5) selected ministries in Kaduna State Government, these are - Ministry of Environmental and Natural Resources, Education, Town Planning and Survey, Water Resources, Youth/Sport and Social Development. The total population of the staff in the said five (5) selected ministries stood at 395, which comprises of officials and staff of Kaduna state.

\subsection{Sampling Techniques}

The sampling technique of any research describes the method used in drawing samples from a population, usually in such a manner that the sample will formulate determination of some hypothesis concerning the population. Simple random sampling approach is employed in this research to select respondents from the five (5) Ministries in Kaduna State Government. This helps to have equal chances of respondents. Meanwhile, a total of three hundred and ninety-five (395) respondents from the five selected Ministries in Kaduna State Government were picked for the study and also for questionnaire administering.

\subsection{Method of Data Collection}

In this research, survey methods of data collection were adopted with relevance to collecting raw data for the study. This study is very effective when studying large populations it ensures that the researcher grasps extensively subject matter under investigations. Survey method is a primary source of obtaining data through the use of instrument of data collection (questionnaire), interview or observation directly from sample size (research field), it establishes a close relationship between the researcher and conditions in the research field. It overrides periodic changes that are not present in the secondary source.

Also as buttress by, Survey as a method of data collection is very relevant to those who study the behavioural characteristics of respondents. Here, formal questionnaire and interview as research instruments are often used to standardize the questions the researcher probes to the subject and provides for efficient and uniform recording of the response that simplifies data presentation and analysis.

\subsection{Instrument of Data Collection}

The instruments employed for this research include questionnaire and interview. Questionnaire is used principally in the research study to collect responses from sample size while Interview is used to elicit responses from respondents of official (Civil Service Commission, Kaduna State Chapter) within the area of study. The use of questionnaire came as a result of its simplicity and accuracy in gathering responses. It is the most widely acceptable and used in social research methodology. 
Questionnaire in this study comprises of forty (40) questions which were in three (3) sections A, B, and C. Section A with eight (8) questions cover biography data of a respondent while section B with eighteen (18) questions covers "motivation and performance" and section C covers research related questions on "strategic staffing and performance". A total number of three hundred and ninety five (395) questionnaires were distributed and the retrieved ones are expected to be used for the analysis.

However, the use of table in data analysis is to summarize the information collated in simple logical manner by use of simple percentage $(\%)$ method as mathematically expressed below:

$$
\text { Total No of respondents } \quad \times 100=(\mathrm{X}) \%
$$

Where:

$$
\begin{array}{ll}
\mathbf{X} & =\text { Calculated percentage for a variable } \\
\text { No of response } & =\text { Number of response to single variable } \\
\text { Total No of respondents } & \text { = Total number of respondents that attempt particular question. }
\end{array}
$$

Hence, this method is very easy and it provides simple and accurate judgement of the relationship that existed among the variables.

\section{DATA PRESENTATION AND ANALYSIS}

From the data gathered from the field of study. Total of 395 questionnaires were administered to some five department(s) in the study area (Ministry) in Kaduna State, 363 out of the 395 questionnaires issued were duly completed and returned accordingly, leaving the remaining questionnaires invalid (32), owing to the fact that they were not properly filled or damaged.

\subsection{Questionnaire Responsiveness Distribution}

The distributions of respondents by their departments are presented in Table 1 below.

Table 1: Response rate by the selected departments

\begin{tabular}{|l|c|c|}
\hline Selected Departments & $\begin{array}{c}\text { Number of questionnaire } \\
\text { Distributed }\end{array}$ & $\begin{array}{c}\text { Number of } \\
\text { questionnaires retrieved }\end{array}$ \\
\hline $\begin{array}{l}\text { Environmental and } \\
\text { Natural Resources }\end{array}$ & 80 & $74(20.3 \%)$ \\
\hline Education & 93 & $90(45.3 \%)$ \\
\hline Town Planning & 86 & $71(19.5 \%)$ \\
\hline Water Resources & 64 & $60(16.5 \%)$ \\
\hline Youth and Sports & 72 & $68(18.7 \%)$ \\
\hline \multicolumn{1}{|c|}{ Total } & 395 & $363(100.0 \%)$ \\
\hline
\end{tabular}

From Table 1, Department of Education had the highest number of questionnaires, which also constituted $45.3 \%$, followed by Environmental and Natural Resources with 20.3\%, next is Town planning with 19.5\%, while Department of Youth and Sports is with $18.7 \%$ questionnaires, and the least goes to Water resources with a total of 60 (16.5\%) questionnaires.

\subsection{Gender Based Distribution}

Table 2: Sex of Respondents

\begin{tabular}{|l|c|c|c|c|c|c|c|c|c|c|}
\hline Variable & \multicolumn{2}{|c|}{$\begin{array}{c}\text { Environmental } \\
\text { And Natural } \\
\text { Resources }\end{array}$} & \multicolumn{2}{|c|}{ Education } & \multicolumn{2}{c|}{$\begin{array}{c}\text { Town } \\
\text { Planning }\end{array}$} & \multicolumn{2}{c|}{$\begin{array}{c}\text { Water } \\
\text { Resources }\end{array}$} & $\begin{array}{c}\text { Youth and } \\
\text { Sports }\end{array}$ \\
\cline { 2 - 11 } & Freq. & $\%$ & Freq. & $\%$ & Freq. & $\%$ & Freq. & $\%$ & Freq. & $\%$ \\
\hline Male & 40 & 54.1 & 47 & 52.2 & 44 & 62.0 & 35 & 58.3 & 30 & 44.1 \\
\hline Female & 34 & 45.9 & 43 & 47.8 & 27 & 38.0 & 25 & 41.7 & 38 & 55.9 \\
\hline Total & 74 & 100.0 & 90 & 100.0 & 71 & 100.0 & 60 & 100.0 & 68 & 100.0 \\
\hline
\end{tabular}

From all indications as shown in Table 2, there are more Male staff in the various department of the ministry than the Female counterparts; considering the frequency distribution and calculated percentages. For instance, out of a total of 74 
respondents from the department of Environmental and natural resources, $54.1 \%$ are males while $45.9 \%$ are said to be females. Similar scenarios are also identified in other ministries.

\subsection{Motivation and Performance}

Table 3: Significant effect of motivation on Employee

\begin{tabular}{|l|l|l|l|l|l|l|l|l|l|l|}
\hline Variable & \multicolumn{2}{|c|}{$\begin{array}{c}\text { Environmental } \\
\text { And Natural } \\
\text { Resources }\end{array}$} & \multicolumn{2}{|c|}{ Education } & \multicolumn{2}{c|}{$\begin{array}{c}\text { Town } \\
\text { Planning }\end{array}$} & \multicolumn{2}{|c|}{$\begin{array}{c}\text { Water } \\
\text { Resources }\end{array}$} & \multicolumn{2}{c|}{$\begin{array}{c}\text { Youth and } \\
\text { Sports }\end{array}$} \\
\cline { 2 - 12 }$y$ & Freq. & $\%$ & Freq. & $\%$ & Freq. & $\%$ & Freq. & $\%$ & Freq. & $\%$ \\
\hline Yes & 56 & 75.5 & 67 & 74.4 & 54 & 76.1 & 43 & 71.7 & 47 & 69.1 \\
\hline No & 14 & 18.9 & 18 & 20.0 & 13 & 18.3 & 11 & 18.3 & 15 & 22.1 \\
\hline $\begin{array}{l}\text { All of the } \\
\text { above }\end{array}$ & 4 & 5.4 & 5 & 5.6 & 4 & 5.6 & 6 & 10.0 & 6 & 8.8 \\
\hline Total & 74 & 100.0 & 90 & 100.0 & 71 & 100.0 & 60 & 100.0 & 68 & 100.0 \\
\hline
\end{tabular}

Considering if motivation has any significant effect on employee's performance is analysed in Table 3 above. It can be seen that majority of the respondents will produce higher rate of efficiency/performance based on the employer's motivating factor in their ministry. This hereby implies that motivation has significant effect on employees' performance than where there is little or no motivation.

Thus, it can be deduced that motivation is of positive significant effect on employee's performance, as respondents with high percentage is of the opinion that motivation brings about employee higher performance while respondents with the low percentage feels motivation is not of any positive significant effect on employee's performance.

\subsection{Motivation Strategy}

Various motivation strategies are being used and this varies from one ministry to another as indicated in the table below (Table 4).

Table 4: Type of motivation strategy

\begin{tabular}{|l|l|l|l|l|l|l|l|l|l|l|}
\hline \multicolumn{1}{|c|}{ Variable } & $\begin{array}{l}\text { Environmental } \\
\text { And Natural } \\
\text { Resources }\end{array}$ & \multicolumn{2}{|c|}{ Education } & \multicolumn{2}{c|}{$\begin{array}{c}\text { Town } \\
\text { Planning }\end{array}$} & \multicolumn{2}{c|}{$\begin{array}{c}\text { Water } \\
\text { Resources }\end{array}$} & \multicolumn{2}{c|}{$\begin{array}{c}\text { Youth and } \\
\text { Sports }\end{array}$} \\
\cline { 2 - 13 } & Freq. & $\%$ & Freq. & $\%$ & Freq. & $\%$ & Freq. & $\%$ & Freq. & $\%$ \\
\hline $\begin{array}{l}\text { Staff training and } \\
\text { development }\end{array}$ & 45 & 73.0 & 62 & 68.9 & 49 & 69.0 & 46 & 76.7 & 52 & 76.5 \\
\hline $\begin{array}{l}\text { Setting target for } \\
\text { employee's }\end{array}$ & 6 & 8.1 & 18 & 20.0 & 16 & 22.5 & 10 & 16.7 & 10 & 14.7 \\
\hline $\begin{array}{l}\text { Incentive for } \\
\text { employees }\end{array}$ & 14 & 18.9 & 10 & 11.1 & 6 & 8.5 & 4 & 6.7 & 6 & 8.8 \\
\hline Total & 74 & 100.0 & 90 & 100.0 & 71 & 100.0 & 60 & 100.0 & 68 & 100.0 \\
\hline
\end{tabular}

Table 4 above clearly shows that majority of the respondents stated that their ministry employ staff training and development as motivation strategy, .i.e. with at least $76.5 \%$ other indicated setting target for employee, .i.e. $20.0 \%$, $22.5 \%, 16.7 \%$ etc, and incentive for employees .i.e. $11.1 \%, 8.5 \%, 8.8 \%$ respectively. 
Table 5: When is the happiest moment in your job?

\begin{tabular}{|c|c|c|c|c|c|c|c|c|c|c|}
\hline \multirow[t]{2}{*}{ Variable } & \multicolumn{2}{|c|}{$\begin{array}{c}\text { Environmental } \\
\text { And Natural } \\
\text { Resources }\end{array}$} & \multicolumn{2}{|c|}{ Education } & \multicolumn{2}{|c|}{$\begin{array}{c}\text { Town } \\
\text { Planning }\end{array}$} & \multicolumn{2}{|c|}{$\begin{array}{c}\text { Water } \\
\text { Resources }\end{array}$} & \multicolumn{2}{|c|}{$\begin{array}{l}\text { Youth and } \\
\text { Sports }\end{array}$} \\
\hline & Freq. & $\%$ & Freq. & $\%$ & Freq. & $\%$ & Freq. & $\%$ & Freq. & $\%$ \\
\hline When promoted & 15 & 20.3 & 32 & 35.6 & 30 & 42.3 & 21 & 35.0 & 23 & 33.8 \\
\hline When given loan & 52 & 70.3 & 47 & 52.2 & 33 & 46.5 & 26 & 43.3 & 37 & 54.4 \\
\hline $\begin{array}{l}\text { When management } \\
\text { shows concern } \\
\text { on problems }\end{array}$ & 7 & 9.5 & 11 & 12.2 & 18 & 11.3 & 13 & 21.7 & 8 & 11.8 \\
\hline Total & 74 & 100.0 & 90 & 100 & 71 & 100 & 60 & 100 & 68 & 100.0 \\
\hline
\end{tabular}

Table 5 above shows that majority of the respondents in various departments claim that the happiest moments in their job is when loan is given to them, i.e. $70.3 \%, 52.2 \% 46.5 \%, 43.3 \%$ and $54.4 \%$, other indicate when they are promoted is the happiest moment in their job, e.g. $20.3 \%, 35.6 \%, 42.3 \% 35.0 \%$ and $33.8 \%$ respectively, and some of the respondentsindicated that the happiest moments in their job is when management shows concern on problem confronting the organization, i.e. $9.5 \% 12.2 \%, 11.3 \%, 21.7$ and $11.8 \%$.

\subsection{Motivating Factors}

Table 6: What motivation you to work harder?

\begin{tabular}{|l|c|c|c|c|c|c|c|c|c|c|}
\hline Variable & \multicolumn{2}{|c|}{$\begin{array}{c}\text { Environmental } \\
\text { And Natural } \\
\text { Resources }\end{array}$} & \multicolumn{2}{|c|}{ Education } & \multicolumn{2}{c|}{$\begin{array}{c}\text { Town } \\
\text { Planning }\end{array}$} & \multicolumn{2}{c|}{$\begin{array}{c}\text { Water } \\
\text { Resources }\end{array}$} & $\begin{array}{c}\text { Youth and } \\
\text { Sports }\end{array}$ \\
\cline { 2 - 12 } & Freq. & $\%$ & Freq. & $\%$ & Freq. & $\%$ & Freq. & $\%$ & Freq. & $\%$ \\
\hline Money & 57 & 77.0 & 57 & 60 & 66.7 & 47 & 66.2 & 38 & 43 & 63.2 \\
\hline Promotion & 14 & 18.9 & 26 & 28.9 & 21 & 29.6 & 18 & 30.0 & 21 & 30.9 \\
\hline Gift & 3 & 4.1 & 4 & 4.4 & 3 & 4.2 & 4 & 6.7 & 4 & 5.9 \\
\hline Total & 74 & 100.0 & 90 & 100.0 & 71 & 100.0 & 60 & 100.0 & 68 & 100.0 \\
\hline
\end{tabular}

Table 6 shows the response of respondents when asked what exactly motivates them to work harder. It can be deduced that, majority of the respondents from the mentioned department clearly stated that money motivates them to work harder, i.e. $77.0 \%, 66.7 \%, 66.2 \% 03.3 \%$ and $63.2 \%$. On the other hand, some of the respondents indicated they were motivated by promotion to work harder .i.e. $18.9 \%, 28.9 \% 29.6 \%, 30.0 \%$ and $30.9 \%$ while others are said to be motivated to work harder by gifts offered to them, e.g. $4.1 \% 4.4 \% 42 \% 6.7 \%$ and $5.9 \%$ respectively.

\subsection{Factors Lowering Job Performance}

Table 7: What are the other factors that lower job performance?

\begin{tabular}{|c|c|c|c|c|c|c|c|c|c|c|}
\hline Variables & \multicolumn{2}{|c|}{$\begin{array}{c}\text { Environmental } \\
\text { And Natural } \\
\text { Resources }\end{array}$} & \multicolumn{2}{|c|}{ Education } & \multicolumn{2}{c|}{$\begin{array}{c}\text { Town } \\
\text { Planning }\end{array}$} & \multicolumn{2}{c|}{$\begin{array}{c}\text { Water } \\
\text { Resources }\end{array}$} & \multicolumn{2}{c|}{$\begin{array}{c}\text { Youth and } \\
\text { Sports }\end{array}$} \\
\cline { 2 - 13 } & Freq. & $\%$ & Freq. & $\%$ & Freq. & $\%$ & Freq. & $\%$ & Freq. & $\%$ \\
\hline $\begin{array}{c}\text { Management } \\
\text { Negligence }\end{array}$ & 59 & 79.7 & 70 & 77.8 & 56 & 78.9 & 48 & 80.0 & 43 & 63.2 \\
\hline Poor salary & 7 & 9.5 & 8 & 8.9 & 7 & 9.9 & 8 & 13.3 & 13 & 19.1 \\
\hline $\begin{array}{c}\text { Lack of } \\
\text { motivation }\end{array}$ & 8 & 10.8 & 12 & 13.3 & 8 & 11.3 & 4 & 6.7 & 12 & 17.6 \\
\hline Total & 74 & 100.0 & 90 & 100.0 & 71 & 100.0 & 60 & 100.0 & 68 & 100.0 \\
\hline
\end{tabular}

Table 7 above depicts other factors lowering job performance. The analysis deduced that most of the respondents in various departments of the organisation stated that other factors that lower performance is said to be management negligence, i.e. $79.7 \%, 77.8 \%, 78.9 \%, 80.0 \%$, and $63.2 \%$, while few of the respondents are of the view that poor salary is one of the other factors that lower job performance, i.e. $9.5 \%, 8.9 \%, 13.3 \%$, and $19.1 \%$, on some of the respondents 
stated that lack of motivation is also part of other factors that lower job performance, i.e. $10.8 \%, 13.3 \%, 11.3 \%, 6.7 \%$, and $17.6 \%$ respectively.

\subsection{Cost Effective Staff Sourcing Analysis}

Table 8: In terms of cost saving, which of these is preferred by your ministry?

\begin{tabular}{|l|c|c|c|c|c|c|c|c|c|c|}
\hline Variables & \multicolumn{2}{|c|}{$\begin{array}{c}\text { Environmental } \\
\text { And Natural } \\
\text { Resources }\end{array}$} & \multicolumn{2}{|c|}{ Education } & \multicolumn{2}{c|}{$\begin{array}{c}\text { Town } \\
\text { Planning }\end{array}$} & \multicolumn{2}{c|}{$\begin{array}{c}\text { Water } \\
\text { Resources }\end{array}$} & \multicolumn{2}{c|}{$\begin{array}{c}\text { Youth and } \\
\text { Sports }\end{array}$} \\
\cline { 2 - 13 } & Freq. & $\%$ & Freq. & $\%$ & Freq. & $\%$ & Freq. & $\%$ & Freq. & $\%$ \\
\hline $\begin{array}{l}\text { External } \\
\text { recruitment }\end{array}$ & 53 & 71.6 & 64 & 71.1 & 42 & 59.2 & 24 & 40.0 & 39 & 57.4 \\
\hline $\begin{array}{l}\text { Internal } \\
\text { recruitment }\end{array}$ & 17 & 23.0 & 21 & 23.3 & 17 & 23.9 & 16 & 26.7 & 25 & 36.8 \\
\hline $\begin{array}{l}\text { Combination of } \\
\text { both }\end{array}$ & 4 & 5.4 & 5 & 5.6 & 12 & 16.9 & 20 & 33.3 & 4 & 5.9 \\
\hline Total & 74 & 100.0 & 90 & 100.0 & 71 & 100.0 & 60 & 100.0 & 68 & 100.0 \\
\hline
\end{tabular}

It can be deduced from Table 8 that majority of the respondents indicated that in terms of cost saving, external recruitment is preferred by their ministry, i.e. $71.6 \%, 71.15,59.2 \%, 40.0 \%$, and $57.4 \%$. On the other hand, some of the respondents from the various departments stated that it is internal recruitment, i.e. $23.0 \%, 23.35,23.9 \%, 26.7 \%$, and $36.8 \%$ respectively while others stated a combination of both, i.e. $5.4 \%, 5.6 \%, 16.9 \%, 33.3 \%$, and $5.9 \%$ respectively.

\subsection{Hypothesis Testing}

Ho: Work performance has significant effect on motivation factor

$\mathbf{H}_{1}$ : Strategic staffing has significant effect on the Nigerian Civil Service

Table 9: How do you assess staffing adopted and its ability to stimulate employee performance?

* Has motivation any significant effect on employees' performance?

\begin{tabular}{|l|c|c|c|c|c|c|}
\hline Model & $\begin{array}{c}\text { Sum of } \\
\text { Squares }\end{array}$ & Df & Mean & Std. Error. & t. Cal. & Sig. \\
\hline Spearman & 93.585 & 1 & 93.585 & .057 & 5.378 & .000 \\
\hline Residual & 59.658 & 331 & $.180 \pm 3.99$ & .032 & 22.787 & .000 \\
\hline Total & 153.243 & 363 & & & & \\
\hline
\end{tabular}

It was considered pertinent to ascertain staffs level of job performance via research activities. On a two-tailed scale, data analysis revealed a mean score of 93.585 for staff motivation. Out of staff job performance based on research, we have mean that lie between .180 to 3.99 , indicating high job performance by the staff of the organization. The hypothesis testing also- shows that chi square calculated for both variables is 93.585 under spearman correlation, and t. calculated (table calculated) reads 5.378 which is higher than the residual, degree of freedom is 1 . So from all indication, it can be deduced from the hypothesis testing that there is significant relationship between strategic staffing and staff motivation. Therefore, the null hypothesis $\left(\mathrm{H}_{1}\right)$ which stated that strategic staffing has significant effect on the Nigerian Civil Service is thus accepted.

\section{CONCLUSION}

It is possible to distinguish factors that have motivational effects from other capacity elements. Some are internal, others are external to or "in the environment" of any given system. The question of motivation is inextricably linked with capacity and needs to be analysed based on enabling environment. Incentive measures, such as salaries, secondary benefits, intangible rewards, recognition or sanctions have traditionally been used to motivate employees to increase performance. Motivators may be positive and/or negative. Reducing dis-incentives or perverse incentives that favour non-conducive behaviour can be more important than inventing new incentives. Incentive systems reside within organizations, their structure, rules, human resource management, opportunities, internal benefits, rewards, sanctions, etc. Whether based on perception or reality, organizational incentive systems do have a significant influence on the performance of individuals and thus the overall organisation. Perhaps the most pervasive structural motivators and incentives are located at the societal level, such as security, rule of law, investment climate, civil service pay or legislation conducive engagement. In a nutshell, it can thus be deduced from the data gathered so far from the study area, that the practice of strategic staffing and motivation plays a significant role on the performance of individuals in any ministry or organisation, most especially those of the study areas of this research, and in like manner, the Nigerian Civil Service as a whole. 


\section{RECOMMEDATIONS}

Based on the study, the following recommendations are made in order to improve organisation productivity and workers performance.

- Management should standardize the workers' motivation policies to reflect the desire and needs of the workers.

-Worker's salaries and wages should be carefully handled to reflect modern day package.

- Management should reward their workers always with promotion and practice fairness in managing the organization's affairs.

- Management should shun favouritism, god-fatherism etc. They could hinder interview from producing the best results.

- Management should promote their employees at the appropriate time.

- It is suggested for management to conduct more study for further clarification of the finding as the study is restricted for generalization due to limited time and scope of the study; hence it was carried out on one organisation.

\section{REFERENCES}

[1] Adebayo, (2010).Motivational Management: Inspiring people for maximum performance, New York: Ebrary Inc.

[2] Adeleke, (2011). How to motivate every employee: 24 proven tactics to spark productivity in the work place, New York: ebrary Inc.

[3] Adeyeye (2009), An Evaluation of Strategy Human Resource Management (SHRM). Practices in Nigeria Universities: The Impact of Ownership Type and Age. European Journal of Economics, Finance and Administrative Sciences

[4] Bechet Ventures, (2006). For Enterpreneurs: Motivating Employees, Retrieved; January 2013, http://www.gaebler.com

[5] Collins (2001), Strategy for Staffing: Employer Branding \& Person Organization Fit. India. Journal of Industrial Relations. Vol 44, No1, Page 35-48

[6] Levering L.M. (2004). Learning and behaviour: a psychobiological perspective, New York.

[7] Mullins N.R. \& Adams W.G. (2005). Towards an integrated model of intrinsic motivation and career selfmanagement, Career Development International. Vol. 11.

[8] Mullins LJ (2005). Management and Organisational Behaviour. Prentice hall. UK 7th Ed. 88(431):1052-1058.

[9] Robbins (2008), The effects of Staffing and Training on Firm Productivity and Profit Growth Before, During and After the Great Recession. Journal of Applied Psychology; Vol 99; No3, Page 361-389

[10] Soanes .J. (2004). Keeping Employees, National Federation of Independent Business, Retrieved; January 2013, http://.nfib.com/pgge/home. 